\title{
ファイバーディスクレーザとその応用
}

\section{Development of Fiber Disk Lasers and Their Applications}

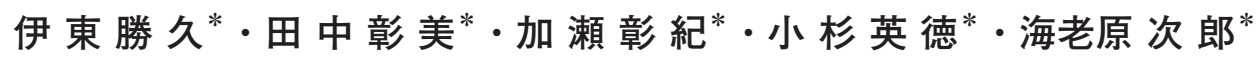 \\ 大村和成 $*$ 瀬上英明* ・宮島博文** ・菅 博文** \\ Katsuhisa ITO, Akiyoshi TANAKA, Akinori KASE, Hidenori KOSUGI, Jiro EBIHARA, \\ Kazushige OMURA, Hideaki SEUE, Hirofumi MIYAJIMA and Hirofumi KAN
}

Key Words: Fiber laser, LD bar, Ytterbium, Cutting, Welding

\section{1. 緒言}

加工用高出力レーザは最近になって再び脚光を浴びつつ ある。切断においては従来からよく使用されている $\mathrm{CO}_{2} レ ー$ ザに加え、ファイバー伝送が可能な $\mathrm{Nd}(\mathrm{Yb})$ ：YAG 結晶固 体レーザによる 3 次元加工、溶接においては高速かつエネ ルギー効率の高いことを理由として、半導体レーザ (LD) 直接集光など、また、高速、高品質溶接を目的に $\mathrm{Nd}(\mathrm{Yb})$ : YAG 結晶固体レーザ、ファイバーレーザが用いられつつあ る。これらのレーザの中でも特にファイバーレーザの成長 はめざましい。 $\mathrm{Nd}(\mathrm{Yb}): \mathrm{YAG}$ 結晶固体レーザやファイバー レーザはロボットや遠隔で扱い易い石英系ガラスファイ バーをレーザ伝送に利用でき、またビーム品質も高い。し かし、YAG 結晶固体レーザは振動に弱い・光軸調整に熟練 が必要、出力調節が簡単ではない、などの理由から実際の 現場での取扱いが難しいという問題点がある。

一方、ファイバーレーザは、集光性に優れ、発振効率が 高く、また小型・軽量で衝撃にも強く、パワー伝送も当然 ファイバーを利用できる。そのため産業用レーザとして高 いポテンシャルをもっている。

さて、ファイバーレーザとは、光通信でよく知られてい る光ファイバーの光の通るコア部分に、レーザを発生、増 幅させる物質（レーザ活性物質；通常 $\mathrm{Yb}^{3+}$ イオン）を添加 した特殊ファイバーを用い、コア内部のみにレーザ光を発 生させるものである。レーザ発生媒体自体が、生まれたレー ザ光を閉じ込めて運ぶ性質を持ち、かつ長いので、通常、 どのレーザにもつきものの、超高精度を必要とする共振器 構造が必要ない。さらに、ファイバーのコアは数〜数十 $\mu$ $\mathrm{m}$ であり、非常に小さいため、高いビーム品質を持つ。し かもビーム形状はほぼ完全な円形で振動、温度外乱などが
加わっても変化しない。そして、発振のエネルギー効率が 高い。

従来ファイバーレーザの主流は Fig. 1 に示すようなダブ ルクラッド構造であり、端面励起であるために効率は 80 〜 90\%という理論值にほぼ近くとれる ${ }^{1), 2)}$ 。しかしながら、ファ イバー端面という非常に狭い領域に励起光を導入する方法 では、出力の拡張性が低く、複雑で高価な励起光集光系を 必要とする。ファイバーレーザの上記の特徵を生かした加 工用レーザを実現するには、ファイバーレーザの高出力化 が必要であった。

\section{2. ファイバーディスクレーザの原理および特徵}

ファイバーレーザの高出力化という課題に対して、われ われは 1997 年から NEDO（独立行政法人 新エネルギー . 産業技術総合開発機構）の“フォトン計測・加工技術の 研究開発”による支援により、ファイバーディスクレーザ (FDL) を開発してきた。FDLの概念図をFig. 2 に示す。レー ザの中心をなす構成物はわれわれが“ファイバーディスク” と呼んでいるものであり、コアにレーザ活性物質を添加し たレーザファイバーを渦巻き状に巻くことを基本に整形し た“ファイバー構造体”である。このファイバーディスク には励起光をディスク内部へ導くための励起光導入ポート が数〜十数力所に設けられている。そして、これらのポー トの先に励起用の高出力 LD モジュールが設置され、簡単 な集光光学系によりポートへ励起光を入射する。ファイ バーディスク内部では励起光は数十本のドープコアを横断 するようにディスクの外周から内周へ向かい、ディスク側 面で反射されジグザグに伝搬するように設計、作製されて いる。励起光はこの伝搬課程でドープコアに少しずつ吸収 され、誘導放出光へと変換される。このとき、コアは一つ

*浜松ホトニクス株式会社レーザーグループ († 431-2103 静岡県浜松市北区新都田 1-8-3)

Hamamatsu Photonics K.K. (1-8-3 Shinmiyakoda, Kita-ku, Hamamatsu-City, Shizuoka, 431-2103 JAPAN)

**浜松ホトニクス株式会社中央研究所（干 434-8601 静岡県浜松市浜北区平口 5000）

Hamamatsu Photonics K.K. (5000 Hirakuchi, Hamakita-ku, Hamamatsu-City, 434-8601 JAPAN) 


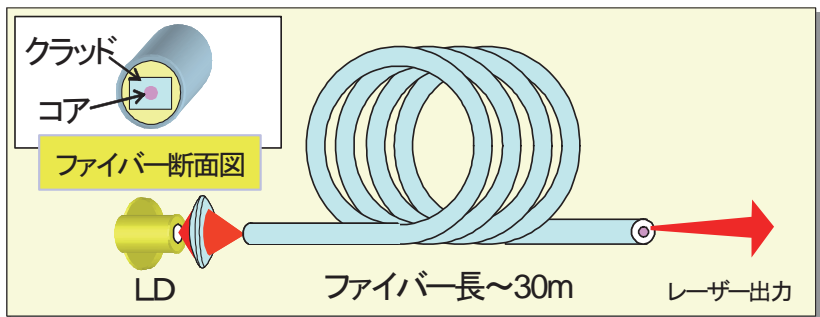

Fig. 1 Schematic diagram of the end pump fiber laser.

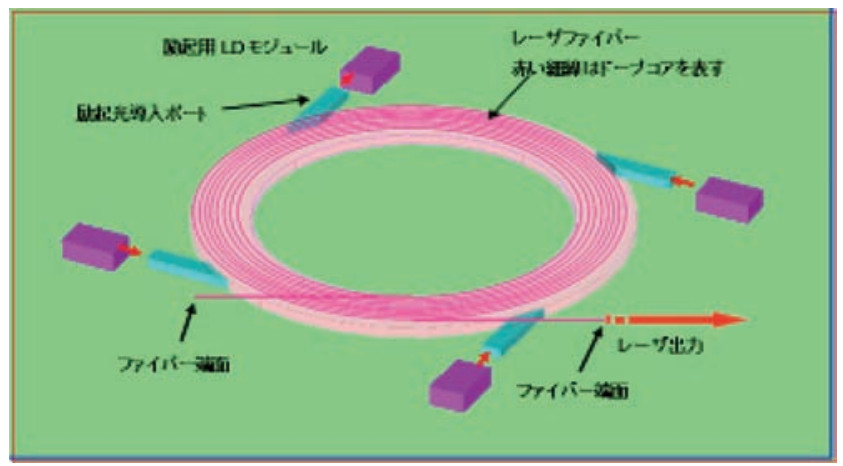

Fig. 2 Schematic diagram of the FDL.

ながりであるのがこの方式のエッセンスである。すなわち 励起光にとっては数十本もの独立したコアであるが、それ ぞれの “コア”で吸収されたエネルギーは、結局一つのレー ザ光の流れに付加されていくことになる。そのため、投入 された励起光は、通常 2 カ所のファイバー端面からのみ出 射される。このように FDL は原理的にファイバーカプラー などのコアだけに直接光を導入するビーム結合、整形コン ポーネントとは全く異なり、本質的にファイバーレーザの 一種である。そのため、ファイバーディスクに投入する励 起光のビーム品質に比べると出射ビーム品質は、指標であ る B.P.P（Beam Product Parameter）で、およそ二桁以上の改 善が望める。FDL は従来のファイバーレーザに加えて固体 レーザに広く使われている側面励起による入力拡張性を併 せ持った方式とも考えられる。この方法では、ファイバー 端面やファイバー 1 本の側面に比べてはるかに広い面を励 起光の導入に利用できるので、高出力の LD バー (LD 発光 源を横一文字に集積したもの）を励起用に用いることがで きる。そのため、原理的には低コストで励起パワーを大幅 に増やすことが可能で、高出力化が容易である。なお、片 方の端面に全反射のミラーのバッチジョイントまたは FBG (Fiber Bragg Gratings) を接続することによって片方からの み両端面出力の合計を出力することも可能である。

一方、ファイバーレーザの光 - 光変換効率は理想的には $80 \%$ を超え、高効率であるが、数百〜数 $\mathrm{k} \mathrm{W}$ という高パワー 励起ではその発熱は無視できない。この点、ファイバーディ

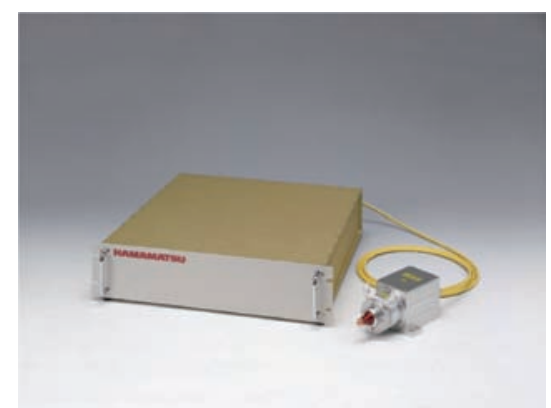

Fig. 3 Photograph of FDL module.

スクでは本体の効率的な冷却のために、作製が容易な平板 状の冷却盤をヒートシンクとして使用できる。そして、ファ イバーデイスク、励起光導入ポート等の構成部品がこれら 金属冷却盤間にリジッドに固定させる事が可能なために、 振動に強いことも特徴である。このように、ファイバーディ スクレーザは取扱いが容易、高出力化への対応が可能、と いう設計思想に基づいて開発されてきた。

また、励起用 LD モジュールに高出力 LDを用いている ため、少ない数の LD モジュールで高出力を実現しており、 万一 LD モジュールに障害が生じても、少ない数の LD モ ジュール交換でメンテナンスができるところがFDL の特長 のひとつでもある。

このファイバーディスクレーザ（FDL）は電気通信大学 植田憲一教授の発案からなり、浜松ホトニクス株式会社 でレーザ装置として開発・作製してきた。われわれはこの FDL の開発にあたり、特殊ファイバー・高出力 LD という 素材・部品段階から手がけてきた。そのため、すべてのコ ンポーネントに関して、詳細な知識が蓄積されているため、 購入部品を組み上げて作製したレーザとは本質的に異なっ ている。すなわちFDL はアイディアの段階から純国産の ファイバーレーザである、といえる。

\section{3. $500 \mathrm{~W}$ ファイバーディスクレーザ}

Fig. 3 に開発した水冷 $500 \mathrm{~W}$ 出力ファイバーディスク レーザのレーザヘッド（励起光源とファイバー部品）およ び加工ヘッド (参考) の外観を示す。このレーザヘッドは、 一般的な 19 インチラックに収まるようなコンパクトなサイ ズで、高さは約 $100 \mathrm{~mm}$ である。また、このレーザへッド を組み込んだ電源・コントローラ外観を Fig. 4 に示す。そ して、レーザの主な仕様を Table 1 に、また発振特性一例 を Fig. 5 に示す。発振波長は約 $1100 \mathrm{~nm}\left(\mathrm{CO}_{2}\right.$ レーザの約 1/9、 $\mathrm{Nd}$ ：YAG 固体レーザに近い)、ファイバー端出力は最 大 $\mathrm{CW}: 580 \mathrm{~W}$ 、定格 $500 \mathrm{~W}$ 、スロープ効率は約 70\%であっ た。NA は 0.12 で、出力ビーム径は $64 \mu \mathrm{m}$ 、出射角は約 5.1 度である。 


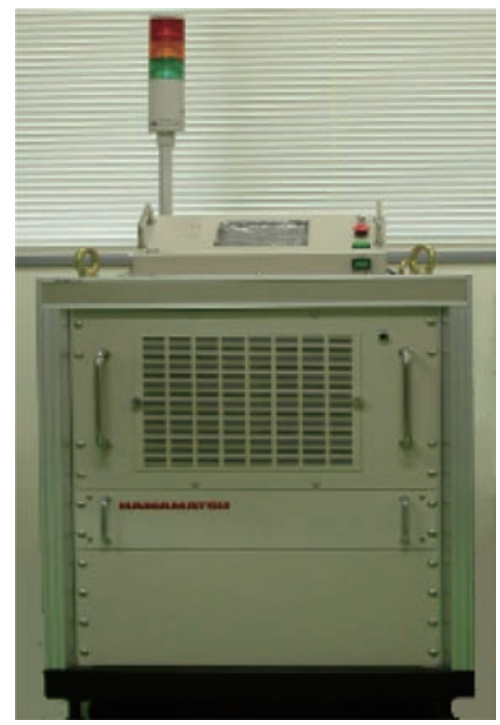

Fig. 4 Photograph of FDL system.

Table 1 Specification of 500W class FDL.

\begin{tabular}{|l|l|}
\hline 波長 & 約 $1.1 \mu \mathrm{m}$ \\
\hline \multirow{2}{*}{ レーザ出力 } & $\mathrm{CW}: 500 \mathrm{~W}$ \\
\cline { 2 - 2 } & $\mathrm{QCW}:$ ピーク $500 \mathrm{~W}, \sim 1 \mathrm{~ms}, 1 \mathrm{kHz}$ \\
\hline パルス幅 $(\mathrm{QCW})$ & $0.05 \sim 10 \mathrm{~ms}$ \\
\hline 周波数 $(\mathrm{QCW})$ & $2 \mathrm{~Hz} \sim 10 \mathrm{kHz}$ \\
\hline コア径 & $85 \mu \mathrm{m}$ \\
\hline $\mathrm{NA}$ & 0.12 \\
\hline 彾却 & 水冷式 \\
\hline
\end{tabular}

\section{4. $\mathrm{kW}$ 級ファイバーディスクレーザ}

ファイバーディスクレーザでは $\mathrm{kW}$ 級レーザの製品化 も達成した。Fig. 6 に製品化したレーザの入出力特性を、 またTable 2 には主な仕様を示す。100〜 $1000 \mathrm{~W}$ 程度まで 出力を設定するためには LDへの電流を調整するだけで簡 単におこなえることもファイバーレーザの特徵の一つであ る。このレーザのビーム品質 B.P.P は $2.9 \mathrm{~mm} \cdot \mathrm{mrad}($ ๖ア径 $85 \mu \mathrm{m}$ のパワー伝送用ファイバー出力光）であり、Fig. 7 に示すように、現在最もポピュラーな高品質ビームの $\mathrm{CO}_{2}$ 加工用レーザの極限值を上回る特性である。

\section{5. ファイバーディスクレーザの応用例}

次にファイバーディスクレーザによる厚さ $0.5 \mathrm{~mm}$ の鋼 板の切断加工実験の様子および切断サンプルの一例を Fig. 8 に示す。約 $120 \mu \mathrm{m}$ 幅での切断が、最大 $14 \mathrm{~m} / \mathrm{min}$ の速度 で可能であった。さらに、 $1 \mathrm{~kW}$ での厚さ $0.5 \mathrm{~mm}$ の鋼板と $\mathrm{Al}$ 合金：厚さ $1 \mathrm{mmt}$ の切断サンプルの写真を Fig. 9(a),(b) に示す。それぞれドロスの少ない切断面である。また、 1

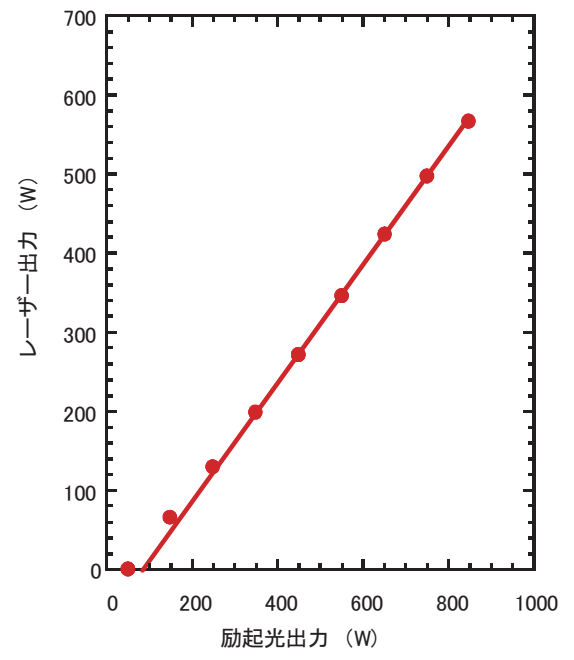

Fig. 5 Output characteristics of 500W class FDL.

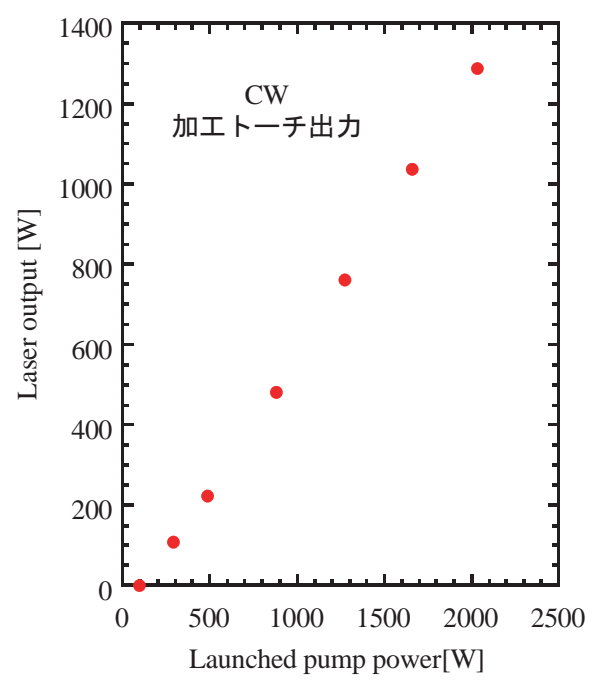

Fig. 6 Output characteristics of $1 \mathrm{~kW}$ class FDL.

Table 2 Specification of $1 \mathrm{~kW}$ class FDL.

\begin{tabular}{|l|l|}
\hline 波長 & 約 $1.1 \mu \mathrm{m}$ \\
\hline \multirow{2}{*}{ レーザ出力 } & $\mathrm{CW}:$ 最大約 $1.3 \mathrm{~kW}$, 定格 $1 \mathrm{~kW}$ \\
\cline { 2 - 2 } & $\mathrm{QCW}:$ ピーク $1 \mathrm{~kW}, \sim 10 \mathrm{~ms}, 1 \mathrm{kHz}$ \\
\hline コア径 & $85 \mu \mathrm{m}$ \\
\hline $\mathrm{NA}$ & 0.12 \\
\hline 冷却 & 水冷式 \\
\hline
\end{tabular}

$\mathrm{kW}$ についてビーム径 $\phi 0.16$ にて厚さ $0.8 \mathrm{~mm}$ の SUS 板の 重ね溶接をした時の表面の様子 (a) と断面の溶接の様子 (b) を Fig. 10 に示す。Fig. 10(b)より、2 枚の SUS が貫通溶接 されていることがわかる。Fig. 11 はFDLによるリモート 溶接を行っている様子である。Fig. 12 は高ビーム品質 $(2.9$ 


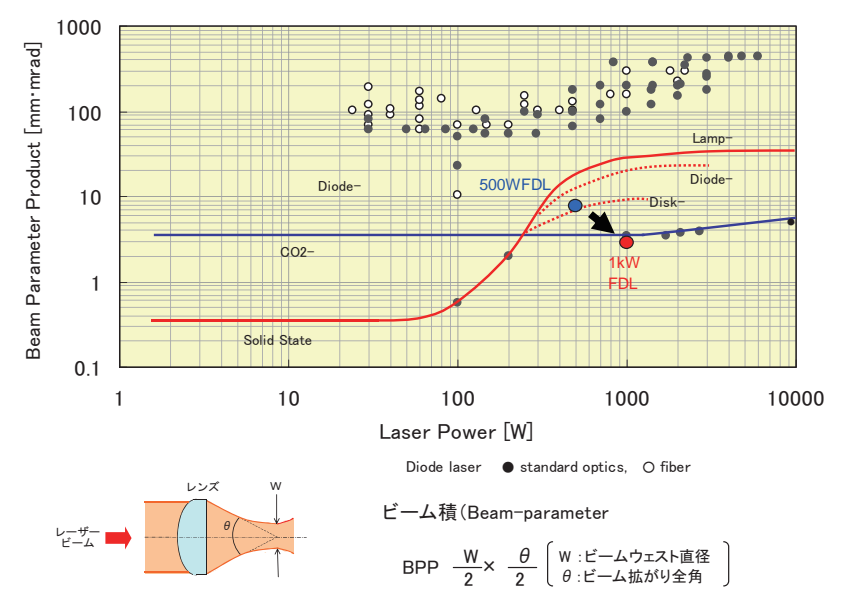

Fig. 7 Beam quality as a function of laser power.

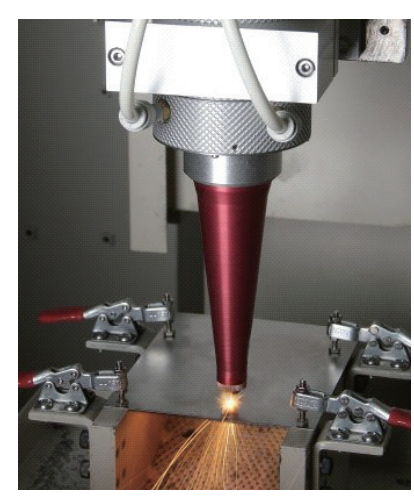

a) 切断の様子

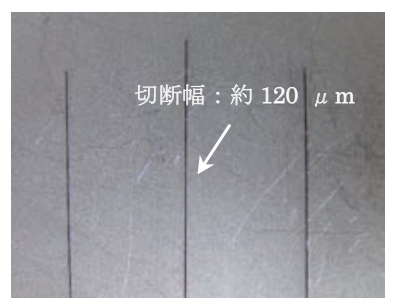

b）切断サンプル一例 $0.5 \mathrm{~mm}$ 厚 鋼板
Fig. 8 Photographs of FDL cutting process (a) and cutting steel sample (b).

$\mathrm{mm} \cdot \mathrm{mrad})$ の FDL で $\phi 8 \mathrm{~mm}$ の SUS 管をカッティングし ている写真である。SUS 管の真上からレーザを照射してい るが、簡単に切断することができた。

このように新しい応用が益々進むものと考えられる。500 $\mathrm{W}$ 出力では金属薄板の切断加工、数 $\mathrm{mm}$ の硬質プラスチッ ク切断加工などに、 $\mathrm{kW}$ 級以上では精密溶接、重ね溶接に 適していると思われる。

\section{6. まとめ}

我々は新しいコンセプトに基づいたファイバーレーザ、 “ファイバーディスクレーザ”の開発を進めている。これは レーザファイバーをディスク状に巻回した媒体を形成し、 非常に広い側面への励起光入力を可能とするものである。 そのため励起入力を大幅に増やせ、高出力化が容易な構成 である。

これまで、開発してきたファイバーディスクレーザは 1 台で定格出力 $\mathrm{CW}: 500 \mathrm{~W}$ と $1 \mathrm{~kW}$ クラスで製品化にも成功

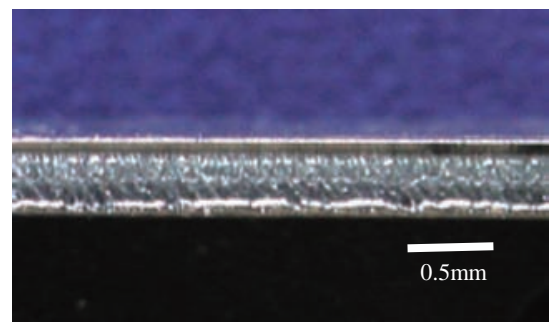

cut surface : SPCC

$\left(0.5 \mathrm{~mm}^{\mathrm{t}}\right.$, pulse mode, $\left.2.4 \mathrm{~m} / \mathrm{min}, 1 \mathrm{~kW}\right)$

(a)

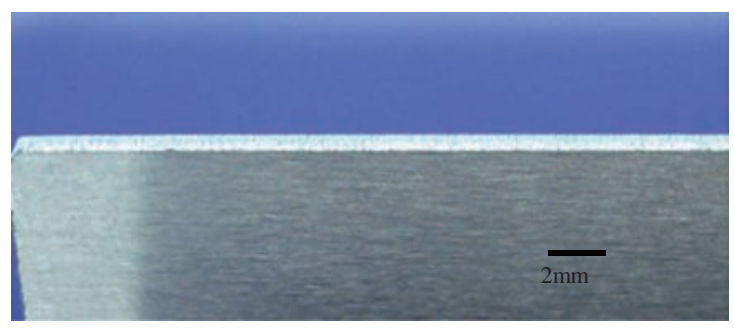

cut surface : Aluminum alloy(A5052)

$\left(1 \mathrm{~mm}^{\mathrm{t}}\right.$, pulse mode, $1 \mathrm{~m} / \mathrm{min}$, peak $\left.1 \mathrm{~kW}\right)$

(b)

Fig. 9 Photographs of FDL cutting surfaces of SPCC (a) and A5052 (b).

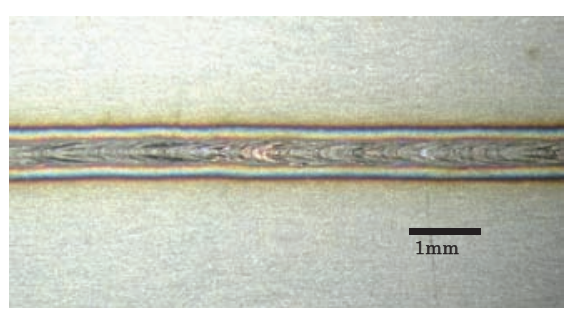

lap welding (penetration bead)

SUS304 $\mathrm{t}=0.8 \mathrm{~mm}^{\mathrm{t}} \times 2$

$6 \mathrm{~m} / \mathrm{min}$

Spot size $\phi 0.16$

(a)

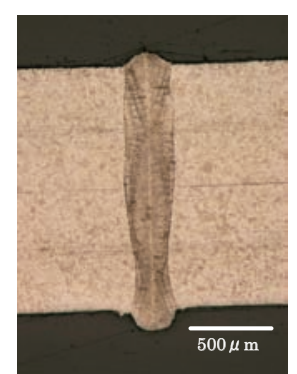

material structure of penetration welding : SUS304 (cross section)

(b)

Fig. 10 Photographs of lap weld bead surface (a) and cross section (b) of SUS 304. 


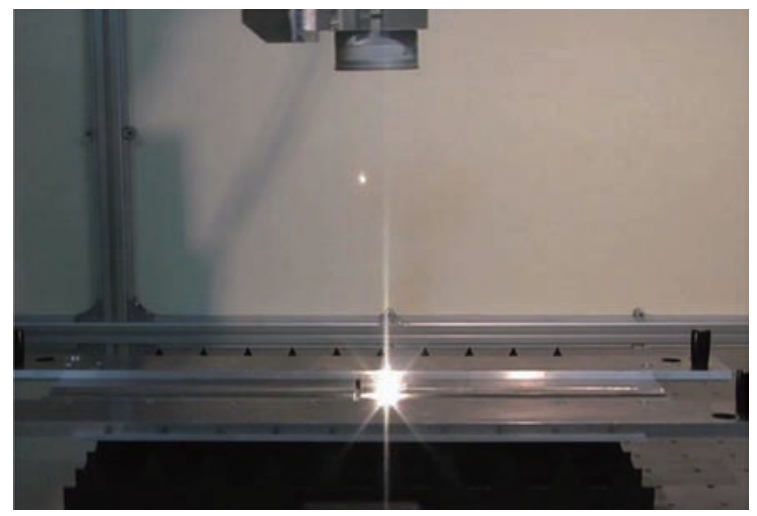

Fig. 11 Photograph of remote welding by FDL, laser power: $1 \mathrm{~kW}$, f: $300 \mathrm{~mm}$.

した。そして、今後もファイバーディスクレーザの更なる 高性能化・高出力化を目的とした開発、製品化を進めてい く予定である。

\section{7. 謝辞}

本ファイバーディスクレーザの開発はNEDO（独立行政 法人 新エネルギー・産業技術総合開発機構) の“フォト ン計測・加工技術の研究開発”による支援に基づいておこ なわれました。また本開発において、研究段階から一貫し てご指導頂いた電気通信大学レーザ新世代研究センターの 植田憲一教授に感謝致します。

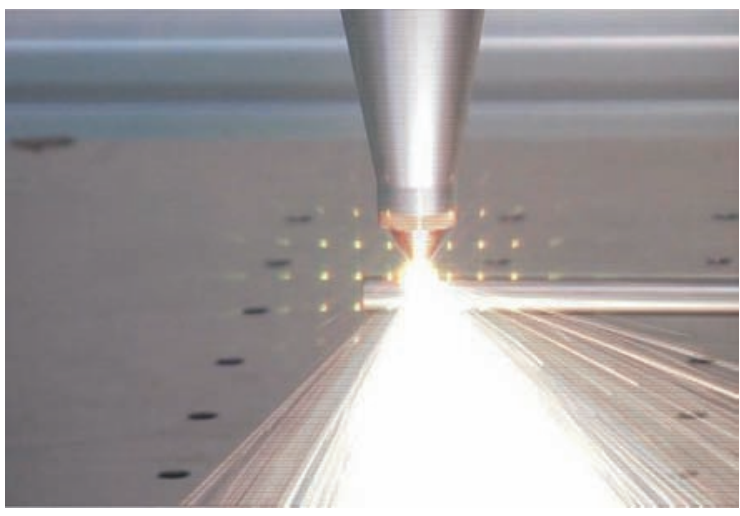

Fig. 12 Photograph of stainless pipe $\phi 8$ cutting by FDL, laser power: $700 \mathrm{~W}$, f: $150 \mathrm{~mm}$.

\section{参考文献}

1) Po H., Cao J.D., Laliberte B.M., Minns R.A., Robinson R.F., Rockney B.H., Tricca R.R. and Zhang Y.H.: High power neodymium-doped single tranverse mode fiber laser, Electron. Lett., 29-17, (1993), 1500.

2) Zenteno L.: High-power double-clad fiber lasers, J. Lightwave Technol., 11-9, (1993), 1435.

3) Valentin Gapontsev. P. and Igor Samartsev, U.S.Patent, US5999673, (1999).

4) 関口宏、伊東勝久、田中彰美、山浦均、菅博文、植田憲一: 1 $\mathrm{kW}$ 出力ファイバーレーザ、レーザ研究、31-8、(2003)、 525. 